INTERMARUM: history, policy, culture. - Issue 8 .

UDC 343.985 .5

DOI 10.35433/history.112011

Voitovych Nataliia,

Candidate of Legal Sciences, Assistant Professor of the Department of Special Historical Disciplines and Law Studies, Zhytomyr Ivan Franko State University voitovichnf@i.ua orcid.org/0000-0003-0805-3919

\title{
HISTORICAL BACKGROUND AND LEGAL ANALYSIS OF SURVEILLANCE IN CRIME PREVENTION
}

\section{Abstract}

The aim of the research is to study the historical preconditions and legal regulation of surveillance in combating crime in the XIX century. At the same time, the author's goal is to compare peculiarities of the instruments of system fight against crime (the method of operational search actions, hereinafter OSA) and covert investigative activities in countries with different forms of government and diverse political systems.

The methodology of the research is: adherence to the principles of objectivity, scientificity and historicism contributed to consistent disclosure of preconditions, content and principles of surveillance as a measure and a method of OSA and covert investigative activities in combating and preventing crime actions. Mutual enrichment with historical and legal methods provided systemity of the research. Historical study of surveillance in combination with the study of regulatory legal acts created new opportunities for interdisciplinary research. The application of general scientific methods, namely systematization, generalization, problem-chronological, comparativehistorical, historical-legal methods allowed to trace the influence of the legal component on the history of introduction and development of surveillance in the "long" XIX century and peculiarities of its usage in the conditions of the newly formed states and political systems in the interwar period.

The scientific novelty lies in a detailed historical and legal analysis of the content of regulatory legal acts concerning legal grounds for surveillance, a comprehensive study of its content, gaps and peculiarities of usage in nondemocratic political regimes.

Conclusions. The article provides historical analysis of evolution and usage of surveillance, which has experienced several stages connected with 
IНТЕРМАРУМ: історія, політика, культура. - Вип. 8.

improving the performance of security functions, in preventing crimes. The attention is focused on the most characteristic features of implementing surveillance as a universal measure of obtaining information and distributing tasks between the states' law enforcement agencies and a means of combating representatives of political forces and structures constituting a real and hypothetical threat to the state / regime. The similarity of performing functions by law enforcement agencies (and the role of surveillance) in the conditions of different state formations, despite fundamental differences in the forms of government and the nature of political systems, is proved.

Key words: surveillance, crime activities, operational search actions, covert investigative activities.

Formulation of the problem. Consideration of historical and legal evolution of surveillance as a method and a measure of operational search actions and covert investigative activities, in terms of historical and legal approach, stimulates the analysis and comparison of its usage in different political systems. Studying historical mechanisms of legal regulation of operational search actions and covert investigative activities, we have an opportunity to focus on the presence of positive examples of their usage and take into account negative practices in order to form a regulatory legal framework in accordance with the standards of human rights and freedoms.

Analysis of recent research and publications. Separate aspects of using operational search measures in the fight against crime were studied by the Soviet scientists V. Dorokhov (Dorokhov, 1966), V. Sushchenko (Sushchenko, 1983) and others. After Ukraine gained independence, the problems of organization and tactics of ensuring search for the accused and defendants by law enforcement agencies' operative units were highlighted in the thesis by S. Apukhtin (Apukhtin, 2013). In the thesis research conducted by V. Chysnikov, the author presented a complex study of organizational, operational search, criminalistic and criminal procedural problems of criminal investigative department in the territory of Ukraine during the Russian Empire (18801917) (Chysnikov, 2017). The preconditions for creation of a complex system of the Soviet state security agencies in the Russian SFSR and Ukrainian SSR during 1917 - early 1920-ies and its organizational and legal basis were analyzed by Kh. Kulhavets (Kulhavets, 2015). O. Yarmysh (Yarmysh, 1992) studied the history of the police and, in 
INTERMARUM: history, policy, culture. - Issue 8.

particular, the administrative and police apparatus and the political investigation bodies of tsarism in Ukraine at the end of the XIX - the beginning of the XX centuries. The research carried out by $\mathrm{Z}$. Peregudova presented an analysis of composition, training, professional qualities and activities of the police spies (Peregudova, 1998). O. Yukhno studied the conceptual principles of operative search prevention of crimes by law enforcement bodies in the modern conditions of Ukraine's development (Yukhno, 2011). Nevertheless, modern historians and lawyers, studying the problems of combating crime, have not provided essential studies of surveillance as a method and a measure of operational search actions and covert investigative activities yet.

Formulation of the aim of the research. The aim of the research is to study the historical preconditions and legal regulation of surveillance in combating crime in the XIX century. At the same time, the author's goal is to compare peculiarities of the instruments of system fight against crime (the method of operational search actions, hereinafter - OSA) and covert investigative activities in countries with different forms of government and diverse political systems.

The outline of the material. In order to clarify the essence of surveillance as a method of operational search actions, it is necessary to know and understand the historical roots, objective necessity, legal basis and principles of conducting such a specific type of Ukrainian law enforcement agencies' activity.

The history of the legal regulation of investigative work dates back to the first edition of the legal code "Ruska Pravda". In this document such forms of search as "tracing" and "pursuit of a trace (persecution)" were mentioned. Surveillance is one of the oldest means of obtaining information still used by the humanity.

From the beginning of the XVIII century, during the reign of Peter I, the surveillance service acquired more or less professional features (Yarmysh, 2009, p. 5). This coincided with the formation of the empire, requiring new protection mechanisms, including a completely new institution at the time - the regular police, which emerged at that time. Simultaneously, a prototype of the political police - the Secret Office of Investigative Affairs (1718) - appeared, the institute of detectives was 
IНТЕРМАРУМ: історія, політика, культура. - Вип. 8.

founded, an instruction allowing to create search teams of servicemen (1719) was issued (Yarmysh, 1992, p. 6).

According to O. Shumylov, search work in those years first received a legal basis (1716). "Rights given to the St. Petersburg Chief of Police General" became a political milestone in the emergence of search work legal regulation. However, these acts were not intended to regulate the actual search activities, and therefore there were insufficient grounds to argue the existence of a systemic approach in the legal regulation of covert work at the time. It was fragmentary in nature and concerned only the central institutions in St. Petersburg and Moscow (Shumylov, 1997, p. 7).

The "Charter of the Deanery, or the Policeman", published in 1782, contained important rules for organization of the police, as well as provisions concerning the competence of the police bodies. Prior to the judicial reform of the 1860-ies, several other acts were passed, regulating the search in certain ways, namely, "On means to correct the police in the cities", "Introduction and Order of the Minister of Police" and "Regulations on the Zemstvo Police". The legal regulation of search work during this period was not clearly formulated (Visotsky, 1903, p. 8).

From the second half of the XIX century there were two waves of regulatory legal transformations in the police system, directly affecting the organization of search work. Those were the reforms of 1862 and 1880. The improvement of legal regulation of search work was marked by development of more effective rules for combating crime and growing revolutionary activity. At that time, there were no separate police units that would perform an operational search function. Consequently, in the middle of the XIX century in the territory of Ukraine, which was part of the Russian Empire, a complex criminogenic situation had been formed, which determined the priority task of creating units of criminal police performing operational search functions. It was planned that the activity of new structural subdivisions would be based on the project of transformation of St. Petersburg city police, developed by V. Frisch in 1863 (Visotsky, 1903, p. 286).

The development of professional criminal police was initiated with the establishment of investigation department in 1866 at the office of St. Petersburg Governor. I. Putilin was appointed as its first chief. At that 
INTERMARUM: history, policy, culture. - Issue 8.

time, main methods of the search police were personal search (involving techniques of operational recognition and short-term implementation), external surveillance, intelligence method, operational inspection. The methods, preferred by I. Putilin, were intelligence surveys and surveillance (Putilin, 1992, p. 12).

The following search offices were established in Kyiv, Kharkiv, Odessa, Katerynoslav and other cities of Ukraine. The basics of their activities were only slightly regulated by the Statute of Criminal Procedure, the Statute on Prevention and Cessation of Crimes, the General Accounting Statute (Complete Collection of Laws of the Russian Federation (from 03/01/1881 to 1913)), as well as numerous departmental acts of the Ministry of Internal Affairs. However, there was no single normative document regulating search activities at that time. Thus, the local authorities issued instructions on the activities of these police units. In 1905 the Instruction for the ranks of the Kyiv search department, compiled by the head of the Kyiv city police search department H. Rudyi, was approved, containing a list of requirements for the search service and its personnel, as well as a number of specific practical recommendations (Rymarenko, Chysnikov, 2005, p. 119, p. 289)

Acts, adopted one after another during 1902-1908, were aimed at eliminating the existing gaps. In addition, a number of regulations on search operations in the army were adopted. Consequently, for the first time in the territory of the Russian Empire, the implementation of OSA was legally regulated by the adoption on July 6, 1908 of the Law "On the Organization of the Search Unit". According to this law, in 89 cities and counties of the Empire in the structure of police departments there were search offices established for carrying out search activities in cases of general criminal nature. The Law defined the subjects who carried out OSA (search departments, as well as chief agents, i.e. professional police officers, and additional agents - spies and detectives); formulated tasks, established rules of search departments' operation and provided control by prosecutors over their activities (Yarmysh, 1992, p. 9). The main provisions of the Law were detailed in the Instruction for the ranks of the search departments dated August 9, 1910.

One of the main achievements of this Instruction was normative consolidation of methods used by search departments. They included 
IНТЕРМАРУМ: історія, політика, культура. - Вип. 8.

systematic control over criminal and vicious elements through covert intelligence and surveillance (Apukhtin, 2013, p. 203).

Notably, the surveillance service was established long before the organization of the Police Department. It consisted mainly of spying agents who were engaged in both criminal and political investigations. However, with the growth of the revolutionary movement and creation of illegal political parties, this kind of separation could no longer suit the police. The first attempt to strengthen the surveillance service and its centralization was creation of a special detachment of trackers (field surveillance) in 1894 at the Moscow Security Department.

The purpose of the newly formed detachment was to fight more successfully against "unreliable elements" and "secret organizations" in the empire. At the time of its formation, it numbered 30 people, and 19,800 rubles a year were allocated for its maintenance. Despite the fact that the detachment existed at the Moscow Security Department, the trackers were sent to various provinces on the instructions of the Police Department to observe the "revolutionary elements" (Ruud, Stepanov, 1993, p. 93).

In 1902, during reorganization of the political search system and creation of search points, the special unit at the Moscow Security Department was disbanded, and most of the personnel were divided into new search points; 20 skilled workers joined the detachment created at the Police Department. In October 1902, the Instruction for the trackers of the special detachment and the trackers of the search and security departments was developed. It consisted of 21 articles. It was used until 1907, when it was replaced by two new instructions.

Enormous efforts made at the time to establish a secret agency, pushed surveillance aside. However, this service remained one of the most important sources of information about the activities of revolutionary forces. With the help of surveillance, the secret agencies' data was developed, the information provided was clarified and verified.

The officials of the Police Department were greatly concerned with the situation regarding field surveillance. Audit data and reports showed insufficient training of the trackers, their low moral and professional qualities, weak service motivation. During the revolution, there was a tendency of losing the most experienced spies due to the fact that the danger of their work increased, and rewards remained unchanged, the 
INTERMARUM: history, policy, culture. - Issue 8.

financial support of the family in case of loss of a breadwinner was not guaranteed.

As free employees, the trackers did not enjoy the rights and privileges of police officers. Trying to bring this service to order, the director of the Police Department M. Trusevych collected ideas and recommendations of the experienced managers, who considered it necessary to create a central school for training trackers, not to use the old methods of surveillance, to be able to act in different situations and not to stop if necessary in the process of search operations.

The Department concluded that a more thorough staff selection, education and training in "modern service responsibilities" were required to improve this area of activity. Among other requirements for a tracker's position applicants were strong health, physical strength, absence of physical defects, good morals. Intellectual abilities and mental development, ingenuity associated with inventiveness were appreciated most. The police spies were required to possess not only the skills of identifying persons by features, familiarity with the area, but also theoretical training. This component presupposed familiarity with the organization of revolutionary parties and the methods of drawing up characteristics of the person under surveillance; carrying out description of clothes, identification of the person on features and differences in uniform, the persons who studied in various educational institutions; knowledge of the conspiracy methods of persons who were surveilled under different circumstances, identification of the apartment where the object of surveillance was discovered in, methods of detention under different circumstances. Women began to be involved in the performance of the trackers' functions (Izmozik, 2002, pp. 591-594).

The first Russian revolution of 1905-1907 made certain corrections in this area. With the direct participation of M. Trusevych, in February 1907 the Instruction on the organization of surveillance, approved by P. Stolypin, was developed and sent to the heads of security departments. It concerned only the activities of trackers. Almost simultaneously, the Instruction on the the organization of visual surveillance related to activities of the heads of security departments, was developed and sent. The Instruction took into account a significant number of recommendations of regional police structures regarding composition, training and activities of the trackers. Preference was 
IНТЕРМАРУМ: історія, політика, культура. - Вип. 8.

given to military reserve lower ranks of non-commissioned officers, not older than 30 years (Rymarenko, Chysnikov, Shynkarenko, 2005, pp. 501-506). The necessary qualities of trackers were considered reliability, honesty, sobriety, agility, courage, ingenuity, patience, perseverance, cautiousness, discipline, good health (especially strong legs), good eyesight, hearing, memory, inconspicuous appearance. The spies could not be persons of Polish and Jewish nationalities (Peregudova, 1998, p. 179).

Taking care of qualitative composition of the surveillance agencies, the Minister of Internal Affairs was faced with the issue of providing increased funding to the trackers, raising their status in the service.

In the reseach made by V. Shendryk, the author cited an excerpt from a report dated November 16, 1906, prepared by M. Trusevych. He noted that duties of trackers were "very responsible", the work was related to constant danger to their lives, but, "having no official rights, they are deprived of the benefits provided to police ranks by current law that complicated the recruitment of agents who were completely morally sound". At the same time, the police officer was aware of other negative consequences of the lack of clarity and certainty of the status and official position of trackers: “ ... agents do not bear the responsibility established by law for officials, therefore, the management is deprived of the possibility of both disciplinary action against them for misconduct, and bringing them to justice for more serious violations of official duties" (Shendryk, 2009, p. 59).

Trackers enlisted in the civil service for the positions of district guards, city guards, officials, performed only their direct duties, they did not wear uniforms, were at the disposal of chiefs of security departments, were not distributed among police guards and were not mentioned in their lists, did not require maintenance expenses from the administration. The young trackers were formally included in the police guard at the expense of private owners, and in fact - of the Police Department.

The department was dissatisfied that the surveillance service continued to be weak in small towns and rural areas, and the recruitment agents were recommended to be employed from local shopkeepers, clerks, visiting traders, commercial agents, booksellers etc. 
INTERMARUM: history, policy, culture. - Issue 8.

In October 1909, the Vice-Director of the Police Department P. Kurlov addressed the Minister of the Internal Affairs with an offer to completely reorganize the visual surveillance service. He raised questions of the school of trackers, the need to organize a central spying detachment for temporary business trips, its leadership. It was emphasized that the Police Department lacked operational and sometimes more objective information about the state of the revolutionary movement after disbandment of this detachment. Under these circumstances, the question of creating a new Instruction on surveillance arose, as far as the Instruction of 1907 on surveillance techniques was outdated, and the techniques themselves had become templates and led to the agents ` failure. In addition, to prove the guilt of revolutionaries in trials, the trackers were interrogated as witnesses, and diaries of visual surveillance were announced, which also led to disclosure of the agents and their tricks. Besides, the Instruction itself was no longer secret, as it was published by the Socialist Revolutionaries in the revolutionary press (Shumylov, 1997, p.15).

In response to P. Kurlov's offer at the end of 1909, a rather influential commission for reorganization of surveillance was formed, involving specialists of the political investigation of the Police Department and the St. Petersburg Security Department. After lengthy discussions, in December 1910 the Central Detachment of Trackers was established at the St. Petersburg Security Department. It consisted of 28 people. The task of the detachment was formulated in the following way: "protection of the imperial majesties during their travels and stays outside their permanent residences and practical training of visual surveillance techniques that would correspond to the modern moment and tactics of the revolutionaries". There were no radical changes in this service, and intensification of the revolutionary parties' terrorist activities led to the fact that the initial purpose of the detachment - the protection of the imperial majesties - came to the fore (Instruction for the Ranks, 1913).

It should be noted that decentralization of the external surveillance service was a reflection of the structure of the criminal police and its position as an additional unit. During this period in the Russian Empire and in the Ukrainian governorates, in particular, the basics of detection and investigation of crimes were developed. Remarkably, the scientific 
IНТЕРМАРУМ: історія, політика, культура. - Вип. 8.

works did not separate the methods of criminal investigation and evidence collection.

The prosecutor of the Kharkiv Judicial Chamber in the Instruction for the ranks of the police on detection and investigation of crimes indicated that the ranks of the police conducted inquiries using surveys, covert surveillance. Thus, covert surveillance was one of the main measures taken by the police to detect crimes. The difficult criminogenic and political situation required an increase in investigative work to secure the evidence base by means of interrogating trackers as witnesses. However, according to the Police Department Circular "On Trackers as Witnesses” № 165710 of January, 16 1914, trackers were required to be interrogated as witnesses if the accusation was based solely on their testimony (Rymarenko, Chysnikov, Shynkarenko, 2005, p. 119, p. 509). Violation of these requirements led to disbandment of the major part of the surveillance units ' personnel.

The February Revolution of 1917 marked a new political era associated with the emergence of national states. The period of 19171921 entered the national history as the Age of the National Revolution. It covered the activities of the Central Council (March 1917 - April 1918), the Hetmanate (April-December 1918), the Directory of the Ukrainian People's Republic (December 1918 - November 1920). This period was characterized by a difficult operational situation in the territory of Ukraine, related to the destruction of the punitive and repressive apparatus of the Russian Empire. In fact, during this period, both the political and criminal police systems were destroyed.

However, some attempts to preserve elements of the destroyed system were observed. Thus, on January 3, 1918, the Mala Rada (the Small Council) passed the "Law on Creation of the People's Army" (Usenko, 1998, 56). This document stated that in the event of an external invasion, an army (people's militia) would be created to defend the Ukrainian People's Republic. The General Secretariat for Military Affairs was instructed to draft a law that would establish the legal basis for the activities of the people's militia. Provisions on the organization of the militia army can be found in the IV Universal of the Ukrainian Central Council. In particular, it outlined the necessity to immediately initiate the formation of people's militia units after disbandment of the regular army. Thus, at the beginning of the state's formation, the Central 
INTERMARUM: history, policy, culture. - Issue 8.

Council took a position of replacing regular military units and regular police with "people's army", which was to become people's militia. After the formation of the People's Militia in March 1917, the development of criminal investigation units and criminal intelligence began. Regulations and instructions were developed. The abovementioned divisions were transformed into criminal intelligence divisions - the Kish of protection of the republican regime. After disbandment of the Kish and the formation of gendarmerie, these units became part of the People's Militia of the Ukrainian People's Republic (Usenko, 1998, p. 13).

After the government headed by Hetman Pavlo Skoropadskyi came to power, the development of a new law enforcement system began with the formation of the State Guard Department within the Ministry of Internal Affairs. On May 18, 1918, the Hetman approved a Temporary provision amending the current laws on the militia and the establishment of the State Guard (Usenko, 1998, p. 14).

It should be noted that during the Hetmanate the professional level of Ukrainian law enforcement officers was quite high. Due to the adopted laws and regulations, various areas of operational and investigative activities of criminal investigation and intelligence units of the State Guard were regulated. In addition, the powers of general criminal and political law enforcement agencies were delineated. Rapid changes of governments, political orientations, and difficult political and economic situations required focusing on resolving the most pressing issues. The formation of professional criminal investigation bodies on a new basis was not completed (Shynkarenko, 2009, p. 112).

Despite the short period of existence, the era of the Ukrainian revolution was characterized by creation of a system of national law enforcement agencies, as well as the development of special forces, to some extent by means of improving operational measures and methods related to gathering information through external and internal surveillance.

During Ukraine's membership in the Soviet Union, surveillance units (in the Soviet tradition, they were given another name, which contained heroic connotations, and thus gave the representatives of this little-respected profession a certain weight and importance intelligence), became part of a newly established criminal investigation. 
IНТЕРМАРУМ: історія, політика, культура. - Вип. 8.

The activity of criminal investigation units was regulated by the decree of the Council of People's Commissars of the USSR "On the organization of criminal investigation" (Vestnik Narodnogo komissariata vnutrennikh del USSR, 1919).

The tasks set for criminal investigation units required special normative regulations. The first step in formation of the legal framework for operational and investigative activities was introduction of the Regulation "On criminal investigation agencies and forensic militia" (Kiyevskiye izvestiya, № 39 (66)). This document for the first time established the organizational structure, directions, forms of criminal investigation and performance of operational search activities. One of the general requirements for criminal investigation agents was covert performance of their duties. In accordance with the Regulations, the institution of trackers was preserved, and this concept was given a broader interpretation, associated with informants, who were assigned the so-called internal surveillance.

On January 2, 1922, the People's Commissariat for Internal Affairs (the NKVD) of the Ukrainian SSR issued an Instruction on the organization of secret agencies in criminal investigation institutions. This document for the first time normatively established the creation of a regular secret apparatus, divided the secret agency into secret spies and covert informants. The general task of the secret agency was to prevent and detect crimes by informing about the crimes prepared, and collecting information about the crimes already committed. This normative act stated that undercover intelligence would include persons who were on a certain monthly salary and who were entrusted with certain tasks.

According to this and other regulations, visual surveillance officers were prohibited from participating in public events conducted by criminal investigation units. To ensure the conceal of observers, they used secret premises and were issued documents with a different name from various institutions. The instruction did not contain clearly formulated principles for the activities of covert surveillance services; there was no classification by category, depending on the functions performed by surveillance officers either. During the NEP, despite certain liberalization, there appeared dangerous tendencies, which would later be intensified and would lead to the formation of the Soviet 
INTERMARUM: history, policy, culture. - Issue 8.

repressive and punitive system. This was especially evident in the activities of the State Political Administration. According to the research carried out by Kh. Kulhavets, "the State Political Administration had a well-organized and extensive network of agents and informants, and in view of this, all relevant information of interest to the authorities, including private conversations, immediately became known to the secret services" (Kulhavets, 2015).

During 1923-1925, the entire system related to the Soviet law enforcement and state security continued to regulate the procedure of inquiry and the activities of the intelligence department (Rymarenko, Chysnikov, Shynkarenko, 2012, p. 20). The Order of the NKVD of the Russian SFSR № 436 / 100s of November 19, 1926 provided for creation of secret agencies of criminal investigation in accordance with the developed Regulations and Instructions. Their main functions were: a) inquiry; b) intelligence; c) development of intelligence materials; d) accounting for the criminal elements (Boltenko, 1978, p. 11). The personnel of the secret units were divided into spies and informants. However, neither in the mentioned Instruction, nor in the following ones, up to the Instruction of 1968 on the organization of operation of the departments (divisions) of militia (intelligence) operational service, the interpretation of concept of external (visual) surveillance was provided.

Under conditions of strengthening of the authoritarian tendencies, the attitude towards law enforcement structures suffered qualitative changes, and their functions were reconsidered towards consolidation of wider powers. The establishment of total control of the "big brother" stimulated the development and expansion of the number of units involved in the supervision and surveillance of both real criminals and hypothetical "enemies of the people". On the eve of the Great Terror, on July 15, 1934, a secret provision on the NKVD appeared, the development and adoption of which involved the Political Bureau of the Central Committee of the All-Union Communist Party of Bolsheviks. This fact confirmed the establishment of party dictatorship and monopoly in the country, intensifying undemocratic tendencies. Among the main operational means, in accordance with the adopted act, new powers of the NKVD were defined, namely: 1) informing, search, surveillance, arrest, seizure, physical search; 2) intelligence surveillance 
IНТЕРМАРУМ: історія, політика, культура. - Вип. 8.

of criminal or suspected groups and organizations; 3) registration of persons identified and suspected of criminal activity and cases filed against them; 4) registration of convicted persons and evictees and special supervision over them; 5) review of correspondence etc. (Kulhavets, 2015).

During World War II, the NKVD special units were used to fight the general criminal activity and to identify hostile agents operating in the near and far rear. The Instruction for Foreign Intelligence Surveillance Agents, introduced in 1942, stated that foreign intelligence was one of the active means of operative-chekist work. This Instruction referred covert external surveillance of persons suspected of hostile activity to foreign intelligence (Smirnov, 1975, p. 31).

Thus, by the end of the 1940-ies, organizational and tactical foundations of external surveillance were formed, structural subdivisions carrying out surveillance were separated, surveillance was divided into two types - general and special ones. Such units became part of the Ministry of Internal Affairs and intelligence existed as part of special units until 1954. That year, the special services were liquidated, and the intelligence units became part of the operational criminal investigation departments, dealing with the issues of the permit system, the search for hiding criminals. The Head of the intelligence department was the Deputy Head of the operational department.

The tasks of the intelligence units included: conducting external surveillance of criminals to trace their connections and preventing crimes in preparation. For operational purposes, the spies were issued service certificates of the standard established for the militia, also they had to have certificates of fictional (legendized) institutions. The spies used the certificates of various state and public organizations.

Surveillance was carried out of persons who were already known to the law enforcement agencies. It allowed to collect complete information about people of interest. The operativists of the public units carried out operative surveillance of unknown persons found during the personal search. This provision still exists. Public operativists have the right to conduct external surveillance during personal search operations.

The tasks of surveillance for that period were:

1) prevention of crimes in preparation;

2) detention of criminals at the moment of an attempted crime; 
INTERMARUM: history, policy, culture. - Issue 8 .

3) detection of criminal activity of persons who underwent intelligence and investigative cases;

4) identification of places the stolen property was stored in, places of concentration of criminal elements;

5) checking the intelligence representatives keeping in contact from operative intelligence agencies;

6) search for persons hiding from investigation and the court;

7) providing other operative measures (searches, lying-in-wait, arrests, secret detentions).

Any of the instructions that appeared in the Soviet period revealed the essence of the surveillance. Only the Instruction on the organization of operation of the departments (divisions) of militia (intelligence) operational service, adopted in 1968, defined surveillance as a set of operative and investigative measures provided by operativists through covert external surveillance of objects of operational interest to law enforcement agencies.

The following regulations duplicated these provisions, only changing the name of the measure: "covert surveillance", "external surveillance", "visual surveillance", "surveillance of a person, thing or place". However, the essence of surveillance and tactics of its application changed depending on the dynamics of social and political relations and the characteristics of the crimes committed.

Conclusions. The use of surveillance in combating crime has underwent several historical stages, and each of them is characterized by certain features. The end of the XIX - the beginning of the XX century (until 1920) covers the pre-revolutionary period and the period of the National Revolution (1917-20) and is characterized by the following features: generalization of the practice of criminal police activity and formation of the normative regulatory base of the use of surveillance in the fight against crime; legal regulation of search activities in this period was mainly in obedience to the law and of secret character; the management of the police was decentralized, which did not contribute to the effective fight against general crimes; the functions of the political police were performed; surveillance tactics to combat general crimes was not developed; an attempt to use external surveillance fillers as witnesses was made; the organization of professional training of surveillance agents was initiated. The period of 1921-1937 was the 
IНТЕРМАРУМ: історія, політика, культура. - Вип. 8.

period of formation of organizational bases of surveillance and its division into general and special, as well as creation of a structural unit, one of the main functions of which was external surveillance, and the first attempts to theoretically substantiate operational and investigative activities were made. However, in the context of authoritarian tendencies and establishment of political terror, these units performed functions, not inherent to them: covert searches and arrests, intelligence covering actions of certain objects, accounting work. On September 29, 1938, the intelligence units were removed from the criminal investigation department and concentrated in a special unit, which reflected the peculiarities of the system operating at the time. Since the early 1990-ies, research on the major issues of the theory and tactics of the use of forces and means of intelligence units in general, and surveillance in particular, has been conducted. The essence and content of surveillance are normatively determined, modern tactics of its implementation are formed. The establishment of independent Ukraine and formation of its law enforcement agencies in the context of the rule of law has contributed to the development of scientific thought about the essence of the use of special measures to effectively combat crime. In 1992, the Law of Ukraine "On the militia" was adopted, the main provisions of which were developed in other legislative and departmental regulations of the Ministry of Internal Affairs of Ukraine. The period of 1992-2012 was a period of active formation of legislative basis of visual surveillance and improvement of its tactics through introduction of the latest advances in science and technology. From November 2012 until present, a period has begun, which is characterized by restructuring of organizational algorithm for connecting and using visual surveillance units of the operational service and formation of the latest regulations, meeting the requirements of a democratic society where human rights and freedoms comprise the highest value.

Gratitude. I would like to thank the members of the editorial board of the journal and the reviewers for their constructive remarks, wishes and consultations provided during the preparation of the article for publication.

Financing. The author did not receive financial support for research and publication of this article. 
INTERMARUM: history, policy, culture. - Issue 8.

\section{References:}

Apukhtin, S. (2013). Orhanizatsiia i taktyka zabezpechennia rozshuku obvynuvachenykh ta pidsudnykh operatyvnymy pidrozdilamy OVS [Organization and Tactics of Providing Search of the Accused and Defendants by Operative Subdivisions of Law Enforcement Agencies]: (dys. ... kandydata yuryd. nauk: 12.00.09 - kryminalnyi protses ta kryminalistyka; sudova ekspertyza; operatyvno-rozshukova diialnist). Dnipropetrovsk, 269 p. [in Ukrainian]

Boltenko, S. (1978). Razvitie pravovykh osnov apparatov ugolovnogo rozyska (po materialam 20-kh godov) Omsk, 136 p. [Boltenko, S. (1978). Development of the legal foundations of criminal investigation apparatus (based on materials from the 20s). Omsk, 136 p. [in Russian]

Visotsky, I. (1903). S.-Peterburgskaya stolichnaya politsiya i gradonachalstvo. Kratkiy istoricheskiy ocherk (1703-1903) [St. Petersburg Metropolitan Police and Town Governorate. Short Historical Outline]. SanktPeterburtg, 340 p. [in Russian]

Dorokhov, V. (1966). Ponyatie dokazatelstva v ugolovnom protsese i operativnoy deyatelnosti [The Notion of an Evidence in the Criminal Procedure and Operative Activity]. Moskva, 43 p. [in Russian]

Izmozik, V. (Uporyadn.) (2002). Zhandarmy Rossii [Gendarmes of Russia]. Sankt-Peterburg: Neva, 649 c. [in Russian]

Instruktsiya chinam Otryada sekretnoy okhrany, po okhrane Ikh Imperatorskikh velichestv vo vremya vysochaishykh puteshestviy i prebyvaniy vne mest postoyannykh rezidentsiy [Instruction for the Ranks of Secret Guard Detachment, on Protection of Their Imperial Highnesses During Gratest Travels and Outside Permanent Residency]. (1913). Sankt-Peterburg: Tipografiya otd. korp. Zhandarmov, 46 p. [in Russian]

Kryminalnyi Protsesualnyi Kodeks [Criminal Procedure Code]. URL : http://www https://zakon.rada.gov.ua/laws/show/4651-17 [in Ukrainian] (Accessed 03 March 2020).

$\mathrm{Ob}$ organizatsii ugolovnogo rozyska [On the Organization of Criminal Investigation]. (1919). Instruktsiya po organizatsyi sovetskoy rabochekrestyanskoy militsii : tsirkulyar NKVS USSR. (1919 г.) // Vestnik Narodnogo komissariata vnutrennikh del USSR. № 3. [in Russian]

Putilin, I. (1992). 40 let sredi ubiyts i grabiteley: zapiski pervogo nachalnika Petrogradskoy sysknoy politsyi [40 Years Among Murderers and Robbers: Notes of the Petrograd Criminal Investigation Department's First Chief]. Kyiv: Svenas, 352 p. [in Russian]

Polnoye sobraniye Zakonov Rossiyskoy Imperii (PSZ) [Complete Collection of Laws of the Russian Federation]: Sobraniye tretye: (S 1.03.1881 g. по 1913g.)(v 33 t., T.8, T.14, T.16 Ch.1). 1885-1916. URL : http://www. 
IНТЕРМАРУМ: історія, політика, культура. - Вип. 8.

http://elib.shpl.ru/ru/nodes/3571-polnoe-sobranie-zakonov-rossiyskoy-imperiisobranie-tretie-c-1-03-1881-g-po-1913-g-v-33-h-t-spb-pg-1885-1916

(Accessed 03 March 2020).

Kulhavets, Kh. (2015) Systema i funktsii radianskykh karalnykh orhaniv RSFRR ta USSR $u$ period iikh formuvannia [System and Functions of the Soviet Penal Establishments of the Russian SFRR and Ukrainian SSR in the Period of Their Formation] URL: file:///C:/Users/Victoria/Downloads/Pupch_2015_2_63.pdf [in Ukrainian] (Accessed 04 March 2020).

$\mathrm{O}$ vvedenii $\mathrm{v}$ deistviye polozheniya ob organakh ugolovnogo rozyska $\mathrm{i}$ sudebno-ugolovnoy militsii [On Introduction of the Regulation On Criminal Investigation Agencies and Forensic Militia] (1919). Postanovleniye NKYu ot 11 maya 1919g. Kiyevskiye izvestiya. № 39 (66). 11 maya. [in Russian]

Peregudova, Z. (1998). Glavnyi filer Rossii [The Main Tracker of Russia]. Moskva, 310 p. [in Russian]

Rymarenko, Yu., Chysnikov, V., Shynkarenko, I. et al. (Otv. red. Yu. Rymarenko) (2005). Antologiya syska [Anthology of Investigation]. Kiev: Znannia Ukrainy, 596 p. [in Russian]

Ruud, Ch., Stepanov, S. (1993). Fontanka, 16: Politicheskiy sysk pri tsaryakh [Fontanka, 16: Political Investigation in the Imperial Period]. Moskva: Mysl, 464 p. [in Russian]

Smirnov, S. (1975). Stanovlenie i razvitie apparatov razvedki organov vnutrennikh del. Operativnaya sluzhba [Formation and development of intelligence apparatus of internal affairs bodies. Operational service]. Moskva: Mysl, 321 p. [in Russian].

Sushchenko, V. (1983). Sledstvenniye situatsii i ikh rol v planirovanii i organizatsyi rassledovaniya prestupleniy [Inquiry Situations and Their Role in Planning and Organizing Crime Investigations]. Problemy sotsialisticheskoy zakonnosti. Vyp. 12. Kharkov. [in Russian]

Usenko, I. (vidp. red.). (1998). Derzhavna varta Ukrainskoi Derzhavu (istoryko-analiz) [The State Guard of the Ukrainian State (Historical Analysis)]. Kyiv, 86 p. [in Ukrainian]

Chysnikov, V. (2017) Syskna politsiia v Ukraini za chasiv Rosiiskoi imperii (1880-1917 rr.): istoryko-pravove doslidzhennia [Criminal Investigation Department in Ukraine in the Period of the Russian Empire: Historical and Legal Research]: (dys. ... doktora yuryd. nauk: 12.00.01 teoriia ta istoriia derzhavy i prava; istoriia politychnykh I pravovykh vchen). Kyiv, 535 p. [in Ukrainian]

Shendryk, V. (2009). Istorychno-pravovyi aspect rozvytku vizualnoho sposterezhennia [Historical and Legal Aspect of the Development of Visual Surveillance]. Pravo i bezpeka, 3. PP. 57-60. [in Ukrainian] 
INTERMARUM: history, policy, culture. - Issue 8.

Shumilov, O. (1997). Uroki istorii normativnogo regulirovaniya operativno-rozysknoy deyatelnosti otechestvennykh spetssluzhb [History Lessons of Normative Regulation of Operative Search Activity of National Special Services]. Moskva: Izd. Shumilova I.I., 240 p. [in Russian]

Yukhno, O. (2011). Kontseptualni zasady operatyvno-rozshukovoho zapobihannia zlochynam orhanamy vnutrishnikh sprav u suchasnykh umovakh rozvytku Ukrainy [Conceptual Bases of Operative Search Prevention of Crimes by Law Enforcement Agencies in the Modern Conditions of Development of Ukraine]: (avtoref. dys. ... doktora yuryd. nauk: 12.00.09. kryminalnyi protses ta kryminalistyka; sudova ekspertyza; operatyvno-rozshukova diialnist). Kharkiv, 36 p. [in Ukrainian]

Yarmysh, O. (vidp. red.). (2009). Zovnishnie sposterezhennia: istoriia ta suchasnist: [Visual Surveillance: History and Modern Times] navch. zb. dokumentiv ta materialiv. Kyiv: «MP Lesia», 664 p. [in Ukrainian]

Yarmysh, O. (1992). Nablyudat neotstypno [To Surveil Relentlessly]. Kyiv: Yurinform, 186 p. [in Russian]

\section{ВойтовИч Наталія. ІСТОРИЧНІ ПЕРЕДУМОВИ ТА ПРАВОВИЙ АНАЛІЗ ВИКОРИСТАННЯ СПОСТЕРЕЖЕННЯ У ПРОТИДІЇ ЗЛОЧИННОСТІ}

\section{Анотація}

Мета роботи - дослідження історичних передумов та правової регламентації спостереження у протидіï злочинності у XIX cm. Одночасно, автор ставила за мету порівняння особливостей використання інструментів системи боротьби із злочинністю (методу оперативно-розшукової діяльності (далі - ОРД) та негласної слідчої (розшукової) дії в державах з різними формами правління та відмінними політичними системи.

Методологія: дотримання принципів об 'єктивності, науковості та історизму сприяли послідовному розкриттю передумов, змісту та принцииів становлення спостереження як заходу, методу ОРД та негласної слідчої (розшукової) дії в боротьбі та протидії злочинності. Взаємне збагачення історичними та правознавчими методами сприяло системності. Історичне дослідження спостереження в поєднанні 3 вивченням нормативно-правових актів створюе нові можливості для міждисииплінарних наукових розробок. Застосування загальнонаукових методів - систематизації і узагальнення та проблемно-хронологічного, порівняльно-історичного, історико-правового методів дозволили прослідкувати вплив юридичної складової на історію запровадження та розвиток спостереження $y$ «довгому» XIX cm. та особливості його 
IНТЕРМАРУМ: історія, політика, культура. - Вип. 8. ISSN 2518-7694 (Print)

ISSN 2518-7708 (Online)

використання в умовах новопосталих держав та політичних систем у міжвоснний період.

Наукова новизна полягає у детальному історико-юридичному аналізі змісту нормативно-правових актів щуодо правових підстав проведення спостереження, комплексно досліджено його зміст, прогалини та особливості використання в умовах недемократичних політичних режимів.

Висновки. У статті здійснено історичний аналіз становлення $i$ використання спостереження у протидї злочинності, яке пройшло кілька етапів, пов'язаних з удосконаленням виконання охоронних функиій. Зосереджено увагу на найбільш характерних особливостях використання спостереження - від універсального заходу отримання інформації та розподілу завдань між правоохоронними органами держав, до засобу боротьби з представниками політичних сил та структур, які несли реальну та гіпотетичну загрозу існування держави/режиму. Доведено подібність виконання функиій силовими структурами (та ролі спостереження) в умовах існування різних державних утворень попри фундаментальні розбіжності $y$ формах державної устрою та характерів політичних систем.

Ключові слова: спостереження, злочинність, оперативно-розшукова діяльність, негласна слідча (розшукова) дія.

\section{Wojtowicz Natalia. HISTORYCZNE PRZESLANKI I ANALIZA PRAWNA WYKORZYSTANIA OBSERWACJI W ZWALCZANIU PRZESTĘPCZOŚCI}

\section{Streszczenie}

Cel pracy to zbadanie przesłanek historycznych $i$ prawnej regulacji spostrzeżenia $w$ zwalczaniu przestępczości $w$ XIX wieku. Jednocześnie celem autora byto porównanie cech wykorzystania instrumentów systemu przeciwdziałania przestępczości (metoda prowadzenia czynności operacyjnorozpoznawczych (dalej - COR) oraz niejawnych działań śledczych (poszukujacych) $w$ krajach o różnych formach rządów $i$ różnych ustrojów politycznych.

Metodologia: przestrzeganie zasad obiektywizmu, naukowości $i$ historyzmu sprzyjało konsekwentnemu ujawnianiu przesłanek, treści i zasad obserwacji jako miary, metody COR i sekretnych działań śledczych (poszukujacych) $w$ przeciwdziałaniu $i$ zwalczaniu przestępczości. Wzajemne wzbogacenie metodami historycznymi i prawnymi dawały dobre warunki ku systematyczności. Historyczne badanie obserwacji $w$ połaczeniu z badaniem aktów normatywnych tworzy nowe możliwości dla studiów 208 


\section{INTERMARUM: history, policy, culture. - Issue 8. ISSN 2518-7694 (Print) ISSN 2518-7708 (Online)}

interdyscyplinarnych. Zastosowanie metod ogólnonaukowych - systematyzacji $i$ uogólnienia, metod problemowo-chronologicznych, porównawczohistorycznych oraz historyczno-prawnych pozwolito prześledzić wplyw sktadnika prawnego na historię wprowadzenia $i$ rozwoju spostrzeżenia $w$ „, dtugim” XIX wieku i cechy jego wykorzystania w warunkach nowopowstatych państw $i$ systemów politycznych $w$ okresie międzywojennym.

Oryginalność naukowa polega na szczegółowej analizie historycznoprawnej treści normatywnych aktów wobec prawnych podstaw spostrzeżenia, całościowo zbadano jego treść, luki $i$ osobliwości stosowania $w$ niedemokratycznych rezimach politycznych.

Wnioski. Artykut zawiera historyczna analize powstawania $i$ wykorzystania metody obserwcji $w$ walce z przestępczościa, która przeszła przez kilka etapów zwiazanych z ulepszeniem realizacji funkcji bezpieczeństwa. $W$ artykule pod uwaga jest najbardziej charakterystyczne cechy stosowania obserwacji - od uniwersalnego środka otrzymania informacji i podziatu zadań między organami ścigania, do sposobu zwalczania sit i struktur politycznych, które stanowiq realne $i$ hipotetyczne zagrożenie dla państwa/reżimu. Udowodniono podobieństwo petnienia funkcji przez organy ścigania (i role obserwacji) $w$ warunkach istnienia różnych formacji państwowych pomimo zasadniczych różnic $w$ formach rządzenia i charakterze ustrojów politycznych.

Stowa kluczowe: obserwacja, przestępczość, czynność operacyjnorozpoznawcza, niejawna czynność śledcza (poszukująca).

The article was received 05.28. 2020

Article recommended for publishing 09. 12. 2020 